\title{
Salt and arterial hypertension — epidemiological, pathophysiological and preventive aspects
}

\author{
Stanisław Surma $\odot^{1}$, Anna Szyndler $\circledast^{2}$, Krzysztof Narkiewicz $\oplus^{2}$ \\ ${ }^{1}$ Faculty of Medical Sciences in Katowice, Medical University of Silesia, Katowice, Poland \\ ${ }^{2}$ Chair and Department of Hypertension and Diabetology, Medical University in Gdańsk, Poland
}

\begin{abstract}
Arterial hypertension in majority of cases is the result of a poor lifestyle. The table salt intake level has changed over the centuries. In populations characterized by a low level of daily salt consumption, hypertension was a rarity and cardiovascular diseases were much less common. More and more food is sold in processed form, and thus containing large amounts of salt. The amount of salt delivered with food significantly exceeds the actual body's needs. Limitation of salt intake should apply to both prevention of hypertension and cardiovascular diseases as well as treatment of people suffering from hypertension. High sodium intake leads to increased systolic and diastolic pressure, increases the risk of cardiovascular disease as well as other diseases such as stomach cancer etc. There are many mechanisms triggered by excessive intake of table salt that lead to an increase in blood pressure. Excess salt adversely affects the entire human body, and in particular the kidneys and blood vessels. National and International Scientific Societies have developed many documents in the form of guidelines on the optimal daily sodium intake. Compliance with the recommendations and limitation of salt intake may significantly reduce the incidence of hypertension in the general population.
\end{abstract}

Key words: salt; sodium; arterial hypertension; cardiovascular disease

Arterial Hypertens. 2020, vol. 24, no. 4, pages: 148-158

DOI: $10.5603 /$ AH.a2020.0012

\section{Introduction}

Nowadays, arterial hypertension $(\mathrm{AH})$ is considered as one of the major health, social and economic problems throughout the world as well as in Poland. According to World Health Organization (WHO) reports, nearly 1 billion people older than 25 are hypertensive. Increased blood pressure is the most important risk factor of death in the world [1]. Raised $\mathrm{BP}$ is a major cause of cardiovascular disease, being responsible for $62 \%$ of strokes and $49 \%$ of coronary events [2], as well as it is a recognized risk factor for heart and renal failure. In patients with $\mathrm{AH}$, the general risk of cardiovascular disease (CVD) is higher compared to those without AH [3]. According to the data from the NATPOL 2011 study (National Study on the Prevalence of Cardiovascular Risk Factors), the most common CVD risk factors in Poland are hypertension (9.5 million; 32\%) and hypercholesterolaemia (18 million; 61\%) [4]. High incidence of hypertension, among other things, is associated with a low level of public awareness (adolescents and adults) about the risk factors of this disease [5, 6]. There are two major forms of hypertension - pri-

Address for correspondence: Anna Szyndler, MD, PhD, Chair and Department of Hypertension and Diabetology, Medical University in Gdańsk, Dębinki 7 Street, 80-952 Gdańsk; e-mail: anna@gumed.edu.pl 


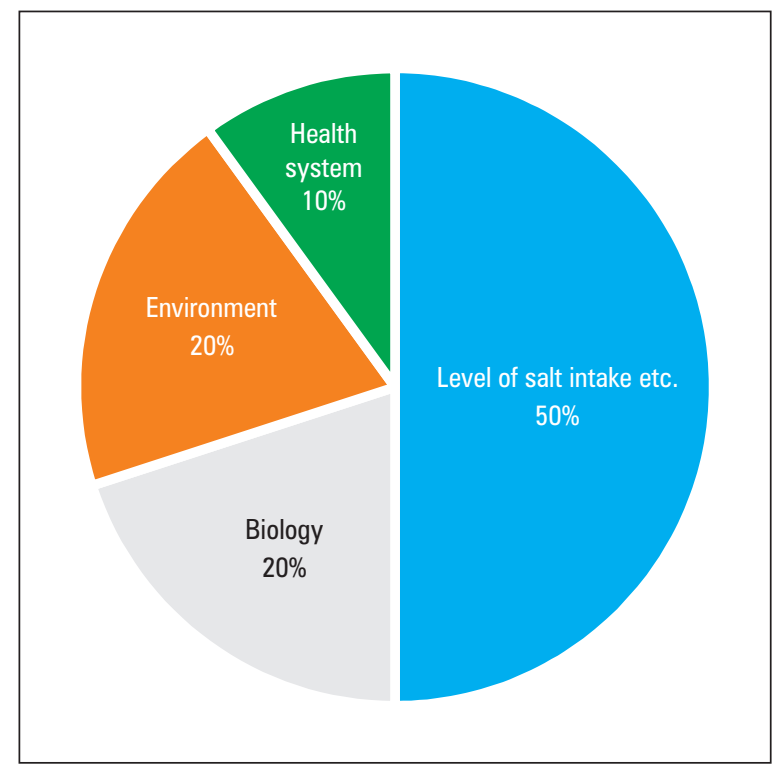

Figure 1. Health determinants. Marc Lalonde, Ottawa 1978

mary hypertension dependent on genetic predisposition and environmental factors (obesity, salt intake, low physical activity) and secondary being the consequence of other diseases (chronic kidney disease, hormonal disorders like the primary hyperaldosteronism, hypercortisolaemia etc.) [7]. The development of primary hypertension depends on several health determinants (including poor lifestyle) described by Marc Lalonde (Fig. 1).

Among the factors that make up lifestyle one is daily salt intake level. The importance of salt consumption in hypertension development has been emphasized for many years, first by Ambard and Beaujard in 1904 and later by Allen, Meneely and Dahl [8].

Sodium chloride $(\mathrm{NaCl})$ is the main form of sodium intake. The correct concentration of sodium in the body is $135-145 \mathrm{mmol} / \mathrm{L}$ [9].

\section{Level of salt intake}

In Poland, approximately 13 grams of salt is consumed daily with food. This classifies our country at one of the top places in Europe [10].

The amount of salt ingested differs significantly around the world - from less than $0.5 \mathrm{~g}$ of salt a day among Indians from the South American Forests, up to $10-12 \mathrm{~g} /$ day in developed countries. Such large salt intake causes increased $\mathrm{Na}^{+}$retention by kidneys, what partially justifies the high incidence of hypertension in developed countries [11]. Data from the INTERSALT study indicate a positive correlation between the amount of salt excreted in urine and the

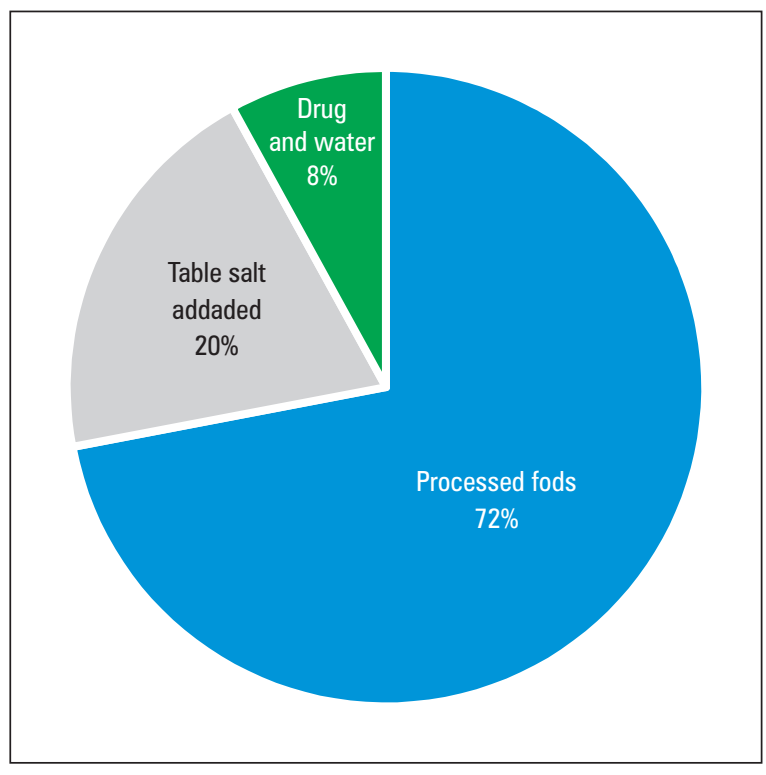

Figure 2. Sources of dietary salt [14]

increase of blood pressure level with progressing age [12]. It is assumed that diurnal sodium excretion in urine, providing normal renal function and correctly collected urine, corresponds to approximately $93 \%$ of the daily sodium intake [13]. Sources of dietary sodium include: processed foods, table salt voluntarily added to meals and salt delivered in water and drugs (Fig. 2) [14].

According to the data from NHANES study (National Health and Nutrition Examination Survey) the highest consumption of salt is noted among men aged 40-49, whereas children aged $2-5$ years of age consume the smallest amount of salt [15]. Italy and Spain are the countries with the largest salt intake observed in Europe (Fig. 3) [16].

Published studies indicate that $72-85 \%$ of salt comes from the processed foods, $15-20 \%$ is added during meal preparation and about $8 \%$ comes from drugs and water [17]. Interesting results on the variation in the supply of sodium on the basis of sex were published by Czerwińska et al. among Warsaw population ( $\mathrm{n}=42$, age $20-30$ years), it was shown that the amount of sodium consumed by women was $3.1 \mathrm{~g} /$ day, while among men $4.7 \mathrm{~g} /$ day. In addition, it was shown that the main source of sodium for men were processed products, while for women salt that was added during the preparation of meals [18].

Studies providing information on salt intake suggest even higher daily salt intake in Poland. In 2008, the average daily intake of salt in men was $14.7 \mathrm{~g}$ and for women $8.6 \mathrm{~g}$ [19]. Data from the EPOGH study showed that in the period 1998-2002 Poles' average 


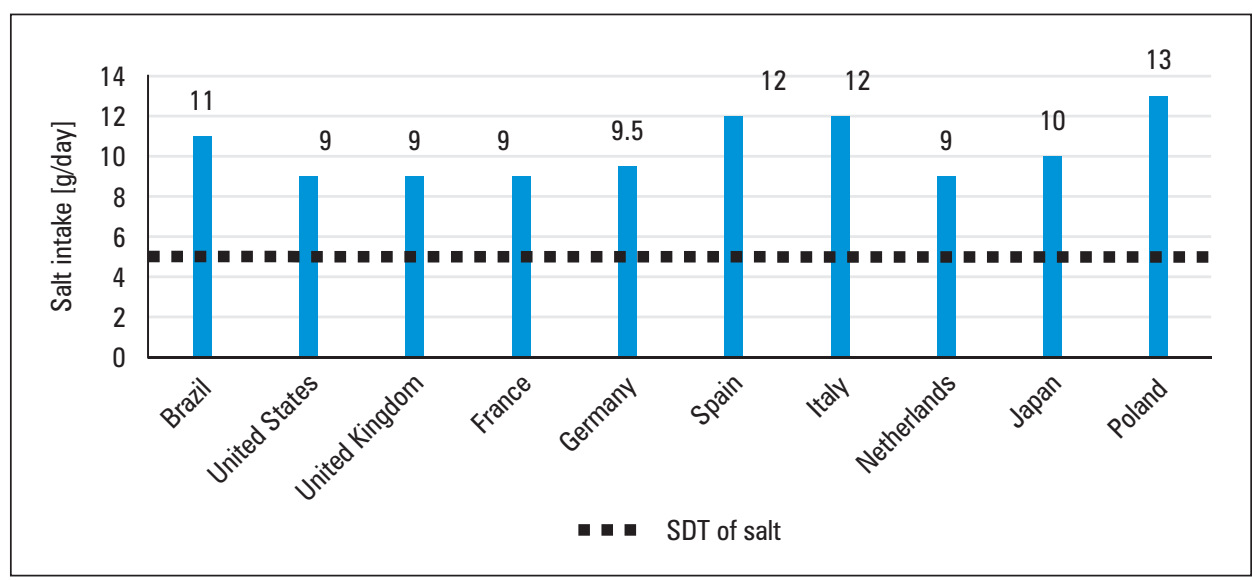

Figure 3. Level of salt intake in selected countries. WHO 2008-2013 [16]. SDT — suggested dietary target for salt

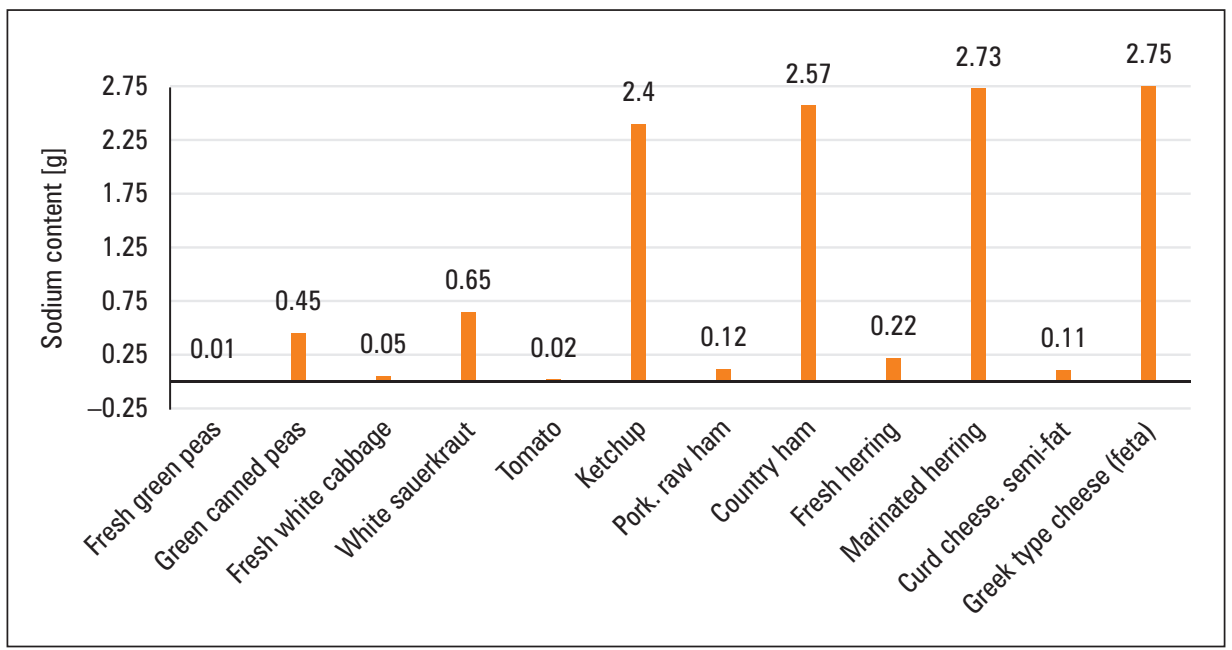

Figure 4. Salt content in selected food products $[9,17]$

daily intake of salt was $15 \mathrm{~g}$. This was the highest level compared to other countries taking part in the study (Belgium, Italy, Russia, the Czech Republic, Romania) [20]. According to the Polish Institute of Food and Nutrition the salt intake in Poland is $10 \mathrm{~g} /$ day [9].

The daily requirement of sodium is about $2 \mathrm{~g}$ (86 $\mathrm{mmol} / \mathrm{l}$; about $5 \mathrm{~g} \mathrm{NaCl}$ ) for both women and men over the age of 18 [21]. Other sources suggest even smaller daily sodium need in adults - about $1.3 \mathrm{~g}$ [22]. It is worth remembering that in 2.5 grams of $\mathrm{NaCl}$ there is about $1 \mathrm{~g}$ of sodium $(\mathrm{Na} ; 43 \mathrm{mmol}$ of $\mathrm{NaCl}$ there is about $2.5 \mathrm{~g} \mathrm{NaCl}$ ).

\section{High salt and cardiovascular mortality}

Data showing that increased salt intake increases mortality are from the INTERSALT Study (Fig. 5) [12].
The incidence of strokes in some regions of Japan is directly proportional to the level of table salt intake. These observations have contributed to an intensive campaign supported by the central government to reduce salt intake. The campaign has been successful - over the decade, average consumption for the whole country has fallen from 13.5 to 12.1 grams of salt a day and consumption in the northern regions has fallen from 18 to 14 grams a day. During the same observation period, there was a decrease in blood pressure in adults and children and an $80 \%$ reduction in stroke mortality [23]. A meta-analysis conducted by Strazullo et al. covering 12 cohort studies showed that an increase in sodium intake by $5 \mathrm{~g} /$ day leads to an increase in the risk of stroke by $23 \%$ and cardiovascular disease by $17 \%$ [24]. The EPOGH study did not confirm the results of the meta-analysis of Strazullo et al. [25]. However, the inclusion of EPOGH results into the meta-analysis 


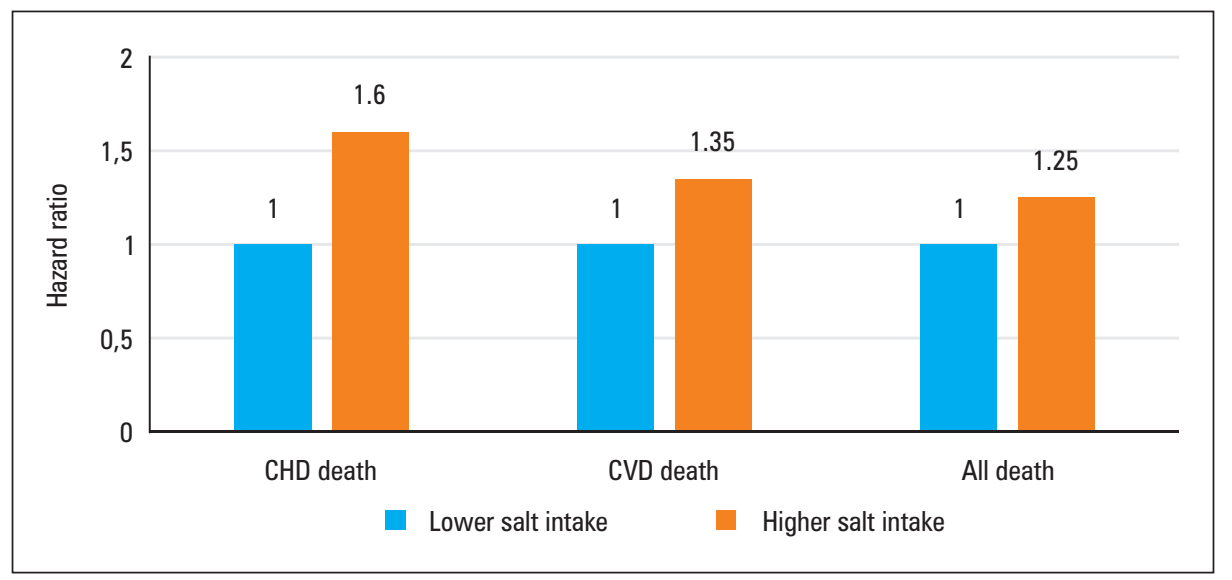

Figure 5. Results from INTERSALT study [12]. CHD — coronary heart disease; CVD — cardiovascular disease

of Strazullo et al. did not change the statistical significance of the results. Based on the analysis of the results of Strazullo et al. and EPOGH trial, it was calculated that reduction of $\mathrm{NaCl}$ consumption by 6 $\mathrm{g} /$ day reduces the risk of stroke by $24 \%$ and cardiovascular diseases by $18 \%$ (a reduction in the number of complications of these diseases by 2.5 million during the year) [26]. Sasaki et al. conducted a study in which a reduction in salt consumption by an average of $4 \mathrm{~g} /$ day in the population of northern Japan caused a reduction in $\mathrm{BP}$ and a reduction in mortality due to a stroke of $80 \%$ [23]. In over 11,000 patients participating in Scottish Heart Health Study, aged 40-59, in long-term follow-up the relationship was found between higher salt and an increased risk of coronary events in women, but this relationship did not occur in the observed men [27]. The TOHP I and TOHP II (Trial of Hypertension Prevention) trials were attended by 3,000 people without hypertension. The subjects were divided into two groups: 1 . with reduced sodium intake $(0.44 \mathrm{mmol} /$ day for 18 months in TOHP I and $0.33 \mathrm{mmol} /$ day for 36-48 months in the TOHP II study); 2. control group. The follow-up period was 10 years in TOHP I, whereas in the TOHP II study it was 15 years. The results of both studies showed a significant reduction (by about 30\%) in the incidence of cardiovascular complications and deaths from cardiovascular causes [28].

The results of the DASH and NHANES III studies showed that reduction of $\mathrm{NaCl}$ consumption by $100 \mathrm{mmol} /$ day (about $5.8 \mathrm{~g} /$ day) reduces the risk cerebrovascular events by $32 \%[29,30]$.

From the blood pressure reduction seen in a metaanalysis [31], it was estimated that a reduction in salt consumption to $5 \mathrm{~g}$ per day would reduce incidence of stroke by $24 \%$ and coronary heart disease by $18 \%$.
This would prevent approximately 35,000 strokes and CHD deaths a year in the UK and approximately 2.5 million deaths worldwide [32].

Hummel et al. reduced sodium intake in 443 patients with heart failure, obtaining a 30-day reduction in the number of deaths [33].

There are well-known observations of the localities in Portugal, where the residents consumed a very large amount of $\mathrm{NaCl}(21 \mathrm{~g} /$ day $)$, while the risk of developing hypertension and stroke was very high. In one of these towns, for two years, there was an intensive educational campaign on reducing salt in food and replacing rich-salt products with less salt. In the place where the consumption of salt decreased by $50 \%$, the mean arterial pressure was $13 / 6 \mathrm{~mm} \mathrm{Hg}$ lower than in the city without medical intervention [34]. Based on the analysis of the results of available studies, $\mathrm{He}$ et al. estimated that limiting salt intake to $3 \mathrm{~g}$ /day leads to a reduction in stroke rates by $13 \%$ and coronary heart disease by $10 \%[26]$.

Since the beginning of the 1970s, Finland has introduced a policy of reducing salt consumption in the entire population. The main strategy included cooperation with the food industry to produce food products with reduced sodium content and raising public awareness of the harmful effects of salt. Over 30 years, salt intake has dropped by one-third with associated systolic and diastolic blood pressure drop. A reduction in the incidence of stroke and mortality from cardiovascular disease by $75-80 \%$ was noted as well as a 6 -years life prolongation. Both the body mass index and alcohol consumption increased over the period, therefore lowering salt intake is the main factor that contributed to the reduction of arterial pressure in Finnish population [35]. 


\section{Salt and blood pressure}

Important data on the effect of salt on blood pressure value is summarized in a paper by $\mathrm{He}$ et al. In the meta-analysis of randomized studies on moderate salt reduction, BP in hypertensive patients decreased by 5.0/2.7 $\mathrm{mm} \mathrm{Hg}$ (SBP/DBP respectively) with restriction of dietary salt from $9.5 \mathrm{~g} /$ day to $5.1 \mathrm{~g} /$ day. In normotensive subjects, the decrease in BP was about half of that observed in hypertensive patients. Therefore, systolic BP decreases about $1 \mathrm{~mm} \mathrm{Hg}$ in hypertensive patients and about $0.5 \mathrm{~mm} \mathrm{Hg}$ in normotensive subjects for each $1 \mathrm{~g} /$ day of salt reduction [36]. A decrease of $40 \mathrm{mmol} /$ day (about $2.33 \mathrm{~g} \mathrm{NaCl}$ ) of salt consumption was related to a decrease in systolic/diastolic blood pressure by $4.3 / 2.0 \mathrm{~mm} \mathrm{Hg}$. Evaluations of a "no added salt diet" on a hypertensive population with high dietary sodium intake (and on no hypotensive drugs) revealed beneficial effects. 24-hour blood pressure recording and 24hour urinary sodium consumption were measured before and after 6 weeks of the "no added salt diet". Despite a modest effect on dietary sodium restriction, the "no added salt diet" significantly decreased systolic and diastolic blood pressure [37]. Lowering the supply of $\mathrm{NaCl}$ in both humans and animals is associated with a decrease in blood pressure, while an increased supply of $\mathrm{NaCl}(250 \mathrm{mmol} /$ day $)$ increases the systolic pressure by $9.4 \mathrm{~mm} \mathrm{Hg}$ [38]. The analysis of 57 studies performed by Jürgens $\mathrm{G}$. et al. of the influence of sodium intake levels on blood pressure concluded that reduced sodium intake in Caucasians with elevated blood pressure has a beneficial effect on reducing blood pressure in the short term. The results suggest that the effect of low versus high sodium intake on blood pressure was greater in Black and Asian patients than in Caucasians [39]. A meta-analysis of 17 studies in hypertensive patients $(\mathrm{n}=734)$ and 11 studies in subjects with normal arterial pressure $(\mathrm{n}=2220)$ showed that the reduction of diurnal sodium urinary excretion by $78 \mathrm{mmol}$ ( $4.6 \mathrm{~g}$ salt) in patients with hypertension was associated with a decrease of $4.97 \mathrm{~mm} \mathrm{Hg}$ in systolic blood pressure and $2.74 \mathrm{~mm} \mathrm{Hg}$ in diastolic pressure. In the subjects with normal blood pressure, a similar reduction in diurnal sodium excretion in the urine led to a decrease in systolic blood pressure by $2.03 \mathrm{~mm} \mathrm{Hg}$ and diastolic blood pressure by $0.99 \mathrm{~mm} \mathrm{Hg}$. In addition, a significant correlation was found between the reduction of urinary sodium excretion and lowering of blood pressure [40].

A study using a 24-hour ambulatory blood pressure monitoring showed that reducing the sodium content in the diet by only $50 \mathrm{mmol}(150-100$ $\mathrm{mmol} /$ day) for 4 weeks is associated with a reduction in blood pressure by $6 \mathrm{~mm} \mathrm{Hg}$ [41]. Meta-analysis of the reduction of $\mathrm{NaCl}$ supply showed that its reduction by $3 \mathrm{~g}$ lowers blood pressure in patients with hypertension by $5.6 \mathrm{~mm} \mathrm{Hg}$, and in people with normal BP by $3.5 \mathrm{~mm} \mathrm{Hg}$ [26]. Similar results were obtained by the Japanese who reduced the salt intake to $2.3 \mathrm{~g} /$ day, thereby lowering the arterial pressure by $3.1 \mathrm{~mm} \mathrm{Hg}$ compared to the places where the salt intake was high [42].

The studies quoted above show a very strong relationship between the amounts of salt consumed level of arterial pressure.

\section{Salt and the risk of developing arterial hypertension}

Salt is one of the major factors that increase blood pressure and is therefore responsible for strokes and heart attacks every year [43]. A number of epidemiological, experimental, and clinical studies have clearly demonstrated that excessive salt intake is related to $\mathrm{BP}$ increase and the progression of hypertension [ 40 , $44,45]$. The influence of excessive sodium intake on blood pressure was first described in 1984 by Norman Kaplan. He stated that the diet in developed societies repeatedly rushes the daily provision for sodium, which may explain the higher incidence of hypertension in these areas [46].

The most important clinical trials concerning the influence of the salt intake level on the blood pressure value are: INTERSALT (1996), DASH SODIUM (2001), TONE (2001) [12, 47, 48].

Based on many studies, it is assumed that the threshold of sodium intake affecting the increase of arterial blood pressure is $50-100 \mathrm{mmol} /$ day. Lack of hypertension and no increase of arterial blood pressure with age in populations with sodium consumption $<50 \mathrm{mmol} / \mathrm{L} / 24$ hours $(<2.91 \mathrm{~g} \mathrm{NaCl})$ justifies the theory of the threshold [49]. Observation of 20 patients with an average blood pressure of 163/100 $\mathrm{mm} \mathrm{Hg}$, consuming an approximately $11.2 \mathrm{~g} \mathrm{NaCl} /$ day showed that lowering the salt intake to $6.4 \mathrm{~g} /$ day during the month, reduced blood pressure to an average of 155/95 $\mathrm{mm} \mathrm{Hg}$. In the following month, after lowering the level of salt consumed to $2.9 \mathrm{~g} /$ day, the arterial pressure was 147/91 mm Hg. After the study, 19 people decided to continue limiting salt intake. After one year their blood pressure was 142/87 mm $\mathrm{Hg}$ [50]. Experimental studies indicate that increasing the level of sodium consumed from 137 to $142 \mathrm{mmol} / \mathrm{L}$ (physiological concentration range!) 
reduces the activity of nitric oxide synthase (NOS) by $25 \%$ [51]. In experimental studies, it was shown that washing smooth muscle cells (myocytes) with $\mathrm{NaCl}$ at a higher than physiological concentration (131-151 mmol/L) leads to hypertrophy of these cells, increased protein synthesis and slowed down protein degradation [52]. Important data comes from the INTERSALT study, which investigated the effect and relation of salt intake and systolic blood pressure [12]. The INTERSALT results, which agree with findings from other diverse studies $[53,54]$ including data from clinical observations, therapeutic interventions, randomized controlled trials, animal experiments, physiologic investigations, evolutionary biology research, anthropologic research, and epidemiologic studies, support the judgment that habitual high salt intake is one of the quantitatively important, preventable mass exposures causing the unfavourable population-wide blood pressure pattern that is a major risk factor for the epidemic of cardiovascular disease. Data from the mentioned INTERSALT study, with 10,079 participants, indicate a positive correlation between the amount of salt excreted in urine and the increase in blood pressure with age, as well as positive correlation of the amount of salt excreted in urine and death from stroke [55]. Based on the results of the INTERSALT study, it was found that an increase in sodium consumption by $6 \mathrm{~g} /$ day causes a rise in blood pressure by $9 \mathrm{~mm} \mathrm{Hg}$ [12]. The Salt Institute (an institution representing kitchen salt producers) criticized the results of the INTERSALT Study. According to this criticism, the rejection of the results of the study from the four centres where $\mathrm{NaCl}$ consumption was the smallest causes the disappearance of the correlation between blood pressure values and renal excretion of sodium. The opinion of the salt institute does not agree with the vast majority of authors of studies on the impact of salt on human health [11].

Confirmation of the results of the INTERSALT study was obtained in the Dahl L.K. study. The results of his work confirmed a positive correlation between the level of daily sodium intake and the prevalence of hypertension in selected geographical areas. The authors summarized that among societies or groups habitually consuming low salt diets (perhaps $5 \mathrm{~g}$ of $\mathrm{NaCl}$ per person per day or less) essential hypertension would be uncommon. Among those consuming high amount of salt (in excess of 10-15 g per person per day) essential hypertension will be common. Individual susceptibility will determine which individual will develop the disease [56].

\section{Sodium consumption influence on other diseases}

The results of numerous studies indicate a relationship between excessive salt intake and the risk of other diseases (Tab. 1).

A six-week reduction in salt intake from 6.2 to 1.7 $\mathrm{g} /$ day gives a noticeable echocardiographic reduction in heart weight (left ventricular mass) [58]. In 9 studies, a significant correlation was observed between the amount of salt in diet and the size of the left ventricle, and the correlation coefficient ranged from 0.22 to 0.61 [59]. Increased sodium intake impairs diastolic heart function in patients with hypertension or type 2 diabetes [60]. Increasing the amount of salt in diet leads within a few weeks not only to the hypertrophy of the left ventricle but also to the fibrosis of this chamber [61]. In 2001, a study was completed in Finland, in which 1173 men and 1263 women were observed for more than 12 years using a saltrich diet. The greater part of ischaemic heart disease and death due to cardiovascular causes was observed. Interestingly, both the incidence of cardiovascular diseases and deaths from this causes did not correlate with the level of blood pressure [62].

In studies on animal models, an increase in sodium consumption led to increased protein loss with urine and significantly impaired kidney's function. Studies in humans at the population level have shown that sodium intake is associated with proteinuria and albuminuria [63]. The reduction of salt intake resulted in a decrease (regardless of the effect on BP) in the incidence of chronic kidney disease and

Table 1. Effects of salt intake on health conditions [57]

\begin{tabular}{|l|c|}
\hline Condition & Level of evidence \\
\hline Blood pressure & ++++ \\
\hline Stroke & +++ \\
\hline Cardiovascular diseases & +++ \\
\hline Left ventricular hypertrophy & +++ \\
\hline Glomerular filtration & +++ \\
\hline Kidney stones (Ca oxalate) & +++ \\
\hline Calcium excretion & ++++ \\
\hline Bone demineralization & ++ \\
\hline Bone fractures & + \\
\hline Stomach cancer & ++ \\
\hline Fluid retention & ++++ \\
\hline Cataract & + \\
\hline Asthma & + \\
\hline Meniere's disease & + \\
\hline Ca - calcium & + \\
\hline
\end{tabular}


Table 2. Effect of sodium on cardiovascular (CV) risk - comparison of results of observational studies

\begin{tabular}{|c|c|}
\hline Theses: & Studies: \\
\hline $\begin{array}{l}\text { Low sodium intake } \\
\text { increases CV risk }\end{array}$ & $\begin{array}{l}\text { Worksite Hypertension Study, } 1995 \\
\text { National Health and Nutrition Examination } \\
\text { Survey I (1998); II (2006); III (2008) } \\
\text { European Project on Genes in Hypertension, } \\
2011\end{array}$ \\
\hline $\begin{array}{l}\text { The level of salt } \\
\text { intake does not affect } \\
\text { CV risk }\end{array}$ & $\begin{array}{l}\text { Scottish Heart Health Study, } 1997 \\
\text { Multiple Risk Factor Intervention Trial, } 2000 \\
\text { Trial of Hypertension Prevention, } 2009 \\
\text { (TOHP) }\end{array}$ \\
\hline $\begin{array}{l}\text { High salt intake } \\
\text { increases CV risk }\end{array}$ & $\begin{array}{l}\text { NHANES I (people with obesity), } 2000 \\
\text { Finish Heart Study, } 2001 \\
\text { Trials of Hypertension Prevention, } 2007 \\
\text { (TOHP) }\end{array}$ \\
\hline
\end{tabular}

proteinuria [64]. Experimental studies have shown that a diet rich in $\mathrm{NaCl}$ leads to a reduction in the angiotensin-converting type II enzyme level (ACEII) and to an increase in angiotensin II (AngII), which results in renal glomerular fibrosis (glomerulopathy) [65]. In studies conducted in postmenopausal women, a relationship was found between the loss of hip bone density and the diurnal sodium excretion in urine, which indicates the unfavourable role of excessive sodium intake in the pathogenesis of osteoporosis [66, 67]. Excessive salt intake also leads to suppression of superoxide dismutase, which results in an increase of the level of $\mathrm{O}_{2}^{-}$. The increase in the concentration of free radicals promotes the development of atherosclerosis [68]. High level of salt intake may also be an indirect cause of obesity by affecting the intake of fluids. It has been shown that in adults, a daily intake of approx. $10 \mathrm{~g}$ of salt leads to an increase in liquid consumption by 350 $\mathrm{mL}$ per day, compared to the amount of liquids, taken with the recommended intake of $5 \mathrm{~g}$ of salt/ day. Because sweet drinks have a significant share in the consumption of liquids, salt intake contributes indirectly to the increase in the amount of calories consumed and the development of overweight and
Table 4. Methods of limiting salt intake [9]

\begin{tabular}{l}
\hline $\begin{array}{l}\text { Methods of limiting salt intake according to the Institute } \\
\text { of Food and Nutrition in Warsaw }\end{array}$ \\
\hline Limiting the addition of salt during the preparation of meals \\
If you need to add salt — add it only at the end of cooking \\
Using fresh and dried herbs instead of salt \\
Replacing NaCl with sodium and potassium salt (mixture of $\mathrm{KCl}$ and \\
NaCl) \\
Choosing products with a lower salt content (GDA — indicated daily \\
intake - \%) \\
$\mathrm{KCl}$ - potassium chloride; GDA - guideline daily amounts
\end{tabular}

obesity [69]. Increased intake of sodium in the diet and urinary excretion of sodium correlate with the greater incidence of stomach cancer. Meta-analysis by D'Elia et al. showed a $68 \%$ higher risk of gastric cancer in the population consuming higher amounts of sodium [70]. In other studies, there was a relationship between the level of sodium consumption and the severity of the course of bronchial asthma and the development of cataracts [57]. A study by Gonzalez et al. conducted in 2012 showed higher levels of insulin and C-reactive protein (CRP), lower high-density lipoprotein (HDL) cholesterol levels and higher insulin resistance in people using a highsodium diet compared to those using a low-sodium diet [71]. Another study conducted in London on a group of 803 men showed no relationship between plasma renin activity and cardiovascular events in both hypertensive and non-hypertensive men [72].

\section{Low salt intake and risk of cardiovascular diseases}

The multi-centre EPOGH (European Project on Genes in Hypertension) study ( $\mathrm{n}=1499$; 6.1-year observation), based on a six-year observation of healthy populations from five European countries, aimed to confirm the thesis that lower sodium intake lowers arterial BP. The results of the EPOGH study confirmed that people who increased their

Table 3. Recommendations for sodium consumption

\begin{tabular}{|l|c|c|}
\hline Organisation & Recommendation & Bibliography \\
\hline World Health Organisation & $5-6 \mathrm{~g} /$ day & {$[83]$} \\
\hline $7^{\text {th }}$ Joint National Committee & No more than $2.3 \mathrm{grams} /$ day $6 \mathrm{~g} \mathrm{NaCl} /$ day) & {$[19]$} \\
\hline American Department of Agriculture and Health & No more than $2.3 \mathrm{grams} /$ day $(6 \mathrm{~g} \mathrm{NaCl} /$ day $)$ & {$[84]$} \\
\hline $\begin{array}{l}\text { European Society of Hypertension } \\
\text { European Society of Cardiology }\end{array}$ & $<5 \mathrm{~g} \mathrm{NaCl} /$ day & {$[85]$} \\
\hline Polish Society of Hypertension & $<5 \mathrm{~g} \mathrm{NaCl} /$ day & \\
\hline NaCl-sodium chloride & & \\
\hline
\end{tabular}


daily salt intake (measured by daily sodium excretion in the urine) showed higher values of systolic blood pressure; for diastolic pressure, there was no statistical significance. The increase in systolic blood pressure was $1.71 \mathrm{~mm} \mathrm{Hg} / 100 \mathrm{mmol}$ sodium (about $6 \mathrm{~g} \mathrm{NaCl}$ ). Analysis of the results of the EPOGH study ( $\mathrm{n}=3681$, 8-year observation) showed that reduction of salt in the diet $(5 \mathrm{~g} \mathrm{NaCl} /$ day $)$ increases the risk of cardiovascular mortality by $56 \%[25,73]$.

The influence of low sodium consumption on the increase of cardiovascular disease is explained by three pathological mechanisms: 1. activation of the renin-angiotensin-aldosterone system; 2 . increase in tissues' insulin resistance; 3. activation of the autonomic nervous system (sympathetic part) $[74,75]$. Three important facts may explain the above research results: 1 . Only a significant reduction in the amount of $\mathrm{NaCl}$ consumed in a short time leads to an increase in plasma renin activity, an increase in the concentration of angiotensin II and aldosterone. Gradual and slow reduction of $\mathrm{NaCl}$ consumption does not lead to the above effects [76]; 2. People taking part in the research could have problems with obeying a salt-poor diet (inadequate compliance); 3 . There is a possibility of a J-curve effect that justifies the desirability of conducting further research on determining the optimal daily dose of $\mathrm{NaCl}$ [72]. Alderman et al. performed an analysis of the results of 23 observational trials, covering the data of 360,000 subjects, and found that cardiovascular complications were highest among those who consumed less than $2.3 \mathrm{~g}$ of sodium and more than 3.4 grams of this element [77]. Analysing the results of the research it can be concluded that there is a J-curve phenomenon of sodium supply and its consumption should fluctuate within certain limits [72].

In the available literature, you can find data confirming three theses (Tab. 2).

\section{Selected pathophysiological mechanisms}

The main pathophysiological mechanisms linking high salt intake with cardiovascular disease are [51, 77-82]:

- increased volume of extracellular fluid — sodium is a strong osmolyte;

- increased stiffness of endothelial cells - epithelial sodium channel $(\mathrm{ENaC})$;

- increase kidney sodium retention - increase in oubaine secretion;
- reducing the degradation of catecholamines - renalase enzyme;

- hyperactivity of the renin-angiotensin-aldosterone system (RAAS);

- reduced NOS activity.

\section{Prevention aspects. Recommendations for sodium consumption}

The DASH study (Dietary Approaches to Stop Hypertension) conducted on 412 people showed a beneficial effect of reducing the amount of sodium in the diet on the level of arterial pressure. In the DASH study, subjects were divided into three diet groups: control - a diet low in vegetables and fruits, a large amount of meat, saturated fatty acids, snacks, sweets; vegetables and fruits - rich in vegetables and fruits, small amount of snacks and sweets; DASH — rich in fruits, vegetables, defatted dairy products, few snacks and sweets, meat, fats, saturated fatty acids. The observation lasted four weeks. Blood pressure was measured by the ABPM method. In the group using a diet rich in vegetables and fruit, systolic blood pressure dropped by $2.8 \mathrm{~mm} \mathrm{Hg}$ on average, and diastolic blood pressure decreased by $1.1 \mathrm{~mm} \mathrm{Hg}$. In the group that used the DASH diet - reduction in systolic blood pressure was $5.5 \mathrm{~mm} \mathrm{Hg}$, diastolic 3 $\mathrm{mm} \mathrm{Hg}$. The effect of diet was most visible among people with hypertension, whose systolic blood pressure dropped on average by $11.4 \mathrm{~mm} \mathrm{Hg}$ and diastolic blood pressure by $5.5 \mathrm{~mm} \mathrm{Hg}$. This reduction in blood pressure is comparable with the use of 1-2 antihypertensive drugs [30]. The continuation of the DASH-Sodium study was the Low-Sodium-DASH study in which the effects of diets from the DASHSodium study were observed in combination with the reduction of salt intake by: $3.5 ; 2.3 ; 1.2$ grams a day for 30 days. Irrespective of the level of sodium in the diet, the DASH diet significantly reduced BP. In groups with low, medium and high levels of salt intake, a reduction in systolic blood pressure was observed, respectively of $5.9 ; 5.0 ; 2.2 \mathrm{~mm} \mathrm{Hg}$, and diastolic of $2.9 ; 2.5 ; 1.0 \mathrm{mmHg}$. The most significant level of blood pressure reduction was observed in the group using the DASH diet together with low salt intake $(8.9 \mathrm{~mm} \mathrm{Hg}$ lower systolic blood pressure, diastolic pressure $4.5 \mathrm{~mm} \mathrm{Hg}$ ), especially in patients with arterial hypertension (lowering systolic blood pressure by $11.5 \mathrm{~mm} \mathrm{Hg}$ ) [76].

So far, the optimal daily sodium intake has not been determined. Experimental, epidemiological and clinical studies indicate the need to gradually reduce the sodium content in the diet. It is recommended to 
limit the consumption of sodium to about 70-100 $\mathrm{mmol} /$ day $(4-5.8 \mathrm{~g} \mathrm{NaCl} /$ day) [83]. The reduction of sodium intake should initially amount to 7-8 $\mathrm{NaCl} /$ day followed by $5-6 \mathrm{~g} \mathrm{NaCl} /$ day. The research results indicate that limiting $\mathrm{NaCl}$ consumption below $3 \mathrm{~g} /$ day may induce adverse consequences [72].

According to the regulations in Poland and Europe, there is an obligation to add potassium iodide (KI) to the salt in an amount of $30 \pm 10 \mathrm{mg} / \mathrm{kJ} / \mathrm{kg}$ salt. These recommendations have led to a significant reduction in the prevalence of endemic volition in children. The recommendations for salt and iodine consumption are mutually exclusive, therefore it is recommended to provide iodine to the body by alternative methods, such as drinking mineralized waters, milk $(200 \mathrm{~mL}$ of milk contains $13-30 \%$ of the daily requirement for iodine), consumption of fresh fish [86-88].

\section{Summary}

Experimental, epidemiological and clinical studies prove that today's dietary habits lead to the development of hypertension, cardiovascular diseases, and kidney diseases. Excessive supply of salt stimulates many mechanisms involved in the development of hypertension. The reduction of sodium intake is particularly recommended for people with hypertension, type 2 diabetes, acute kidney disease (chronic renal failure with hypertension), and obesity, because these diseases have higher susceptibility to high blood pressure [17]. Limiting the consumption of sodium significantly improves the effects of antihypertensive drugs (in addition to calcium antagonists) and can even replace 1-2 antihypertensive drugs [47] in some cases. Unfortunately, limiting sodium in diet is difficult, because the vast majority of sodium is delivered in processed products (according to various studies - 72-85\%). The immediate possibility of reducing sodium consumption is preparation of fresh foods at home. For people who have problems with limiting the amount of sodium consumed, it is recommended to use potassium chloride $(\mathrm{KCl})$ instead of sodium chloride $(\mathrm{NaCl})$ [87]. A study of veterans living in Taiwan (2.5 years of observation) showed that a $17 \%$ reduction in $\mathrm{NaCl}$ consumption with a $76 \%$ increase in $\mathrm{KCl}$ consumption resulted in a $40 \%$ reduction in the risk of cardiovascular death [89] Recommendations concerning the salt intake by healthy people are not conclusive - it is not known exactly to what values the salt supply is to be reduced.

\section{Potential conflict of interest}

The authors do not declare any conflict of interest.

\section{References}

1. Kannel W. Blood Pressure as a Cardiovascular Risk Factor. JAMA. 1996; 275(20): 1571, doi: 10.1001/jama.1996.03530440051036, indexed in Pubmed: 8622248.

2. World Health Report 2002: Reducing risks, promoting healthy life. World Health Organisation, Geneva 2002. www.who.int/ whr/2002 (28 May 2010).

3. Mendis S, Puska P, Norriving B. (eds). Global Atlas of Cardiovascular Disease Prevention and Control. WHO, Geneva 2011.

4. Zdrojewski T, Rutkowski M, Bandosz P, et al. Prevalence and control of cardiovascular risk factors in Poland. Assumptions and objectives of the NATPOL 2011 Survey. Kardiol Pol. 2013; 71(4): 381-392, doi: 10.5603/KP.2013.0066, indexed in Pubmed: 23788344.

5. Surma S, Szyndler A, Narkiewicz K. Awareness of selected heart disease risk factors among young people. Choroby Serca i Naczyń. 2017; 14(4): 186-193.

6. Surma S, Szyndler A, Narkiewicz K. Awareness of hypertension and other risk factors for cardiovascular disease in the adult population. Choroby Serca i Naczyń. 2018; 15(1): 14-22.

7. Kaplan NM. Clinical hypertension. Williams\&Wilkins, New York 1998.

8. Freis E. The role of salt in hypertension. Blood Press. 2009; 1(4): 196-200, doi: 10.3109/08037059209077662, indexed in Pubmed: 1345215 .

9. Jarosz M, Szponar L, Rychlik E, Wierzejska E. Woda i elektrolity . In: Jarosz M. ed. Normy żywienia dla populacji polskiej - nowelizacja. Instytut Żywności i Żywienia, Warszawa 2010: 143-153.

10. Polacy a spożycie soli. Raport MNIEJ SOLI. http://www.mniejsoli.pl/Raport_Mniej_Soli.pdf.

11. He FJ, Burnier M, Macgregor GA. Nutrition in cardiovascular disease: salt in hypertension and heart failure. Eur Heart J. 2011; 32(24): 3073-3080, doi: 10.1093/eurheartj/ehr194, indexed in Pubmed: 21705359.

12. Intersalt Cooperative Research Group. Intersalt: an international study of electrolyte excretion and blood pressure. Results for 24 hour urinary sodium and potassium excretion. BMJ. 1988; 297(6644): 319-328, doi: 10.1136/bmj.297.6644.319, indexed in Pubmed: 3416162.

13. Karppanen H, Mervaala E. Sodium intake and mortality. Lancet. 1998; 351(9114): 1509, doi: 10.1016/s0140-6736(05)78896-6, indexed in Pubmed: 9605823.

14. European Society of Cardiology. www.escardio.org.

15. National Health and Nutrition Examination Survey (NHANES), 2007-2008. ICPSR Data Holdings. 2010, doi: 10.3886/ icpsr25505.v3.

16. Pelofske E. Healthy food can taste good. https://www.preparedfoods.com/articles/116709-formulating-healthy-foods.

17. Adamczak M, Słabiak-Błaż N, Ritz E. Sól a nadciśnienie tętnicze. In: Więcek A, Kokot F. ed. Postępy w nefrologii i nadciśnieniu tętniczym. T 9. Medycyna Praktyczna, Kraków 2010: 11-17.

18. Czerwińska D, Czerniawska A. Ocena spożycia sodu, z uwzględnieniem soli kuchennej jako jego źródło, w wybranej populacji warszawskiej. Rocz Panstw Zakl Hig. 2007; 58: 205-210.

19. Lambers Heerspink HJ, Navis G, Ritz E. Salt intake in kidney disease - a missed therapeutic opportunity? Nephrol Dial Transplant. 2012; 27(9): 3435-3442, doi: 10.1093/ndt/gfs354, indexed in Pubmed: 22942175.

20. Stolarz K, Staessen JA, Kawecka-Jaszcz K, et al. European Project On Genes in Hypertension (EPOGH) Investigators. Genetic variation in CYP1 1B2 and AT1R influences heart rate variability conditional on sodium excretion. Hypertension. 2004; 44(2): 156-162, doi: 10.1161/01.HYP.0000135846.91124.a5, indexed in Pubmed: 15238568.

21. Nutrient Reference Values for Australia and New Zealand. Sodium. https://www.nrv.gov.au/nutrients/sodium.

22. Bańkowski E. Biochemia - podręcznik dla studentów uczelni medycznych. Wyd. III. Edra Urban \& Partner, Wrocław 2016. 
23. Sasaki N. The salt factor in apoplexy and hypertension: epidemiological studies in Japan. In: Yamori Y. ed. Prophylactic approach to hypertensive diseases. Raven Press, New York 1979: 467-474.

24. Strazzullo P, D'Elia L, Kandala NB, et al. Salt intake, stroke, and cardiovascular disease: meta-analysis of prospective studies. BMJ. 2009; 339(8): b4567-701, doi: 10.1136/bmj.b4567, indexed in Pubmed: 19934192.

25. Stolarz-Skrzypek K, Kuznetsova T, Thijs L, et al. European Project on Genes in Hypertension (EPOGH) Investigators. Fatal and nonfatal outcomes, incidence of hypertension, and blood pressure changes in relation to urinary sodium excretion. JAMA. 2011; 305(17): 1777-1785, doi: 10.1001/jama.2011.574, indexed in Pubmed: 21540421

26. He FJ, MacGregor GA. How far should salt intake be reduced? Hypertension. 2003; 42(6): 1093-1099, doi: 10.1161/01. HYP.0000102864.05174.E8, indexed in Pubmed: 14610100.

27. Tunstall-Pedoe H, Woodward M, Tavendale R, et al. Comparison of the prediction by 27 different factors of coronary heart disease and death in men and women of the Scottish Heart Health Study: cohort study. BMJ. 1997; 315(7110): 722-729, doi: 10.1136/ bmj.315.7110.722, indexed in Pubmed: 9314758

28. Cook NR, Cutler JA, Obarzanek E, et al. Long term effects of dietary sodium reduction on cardiovascular disease outcomes: observational follow-up of the trials of hypertension prevention (TOHP). BMJ. 2007; 334(7599): 885-888, doi: 10.1136/ bmj.39147.604896.55, indexed in Pubmed: 17449506.

29. Hajjar IM, Grim CE, George V, et al. Impact of diet on blood pressure and age-related changes in blood pressure in the US population: analysis of NHANES III. Arch Intern Med. 2001; 161(4): 589-593, doi: 10.1001/archinte.161.4.589, indexed in Pubmed: 11252120

30. Sacks FM, Svetkey LP, Vollmer WM, et al. DASH-Sodium Collaborative Research Group. Effects on blood pressure of reduced dietary sodium and the Dietary Approaches to Stop Hypertension (DASH) diet. DASH-Sodium Collaborative Research Group. N Engl J Med. 2001; 344: 3-10, doi: 10.1056/ NEJM200101043440101, indexed in Pubmed: 11136953.

31. Perry IJ, Beevers DG. Salt intake and stroke: a possible direct effect. J Hum Hypertens. 1992; 6(1): 23-25, indexed in Pubmed: 1583626.

32. Xie JX, Sasaki S, Joossens JV, et al. The relationship between urinary cations obtained from the INTERSALT study and cerebrovascular mortality. J Hum Hypertens. 1992; 6(1): 17-21, indexed in Pubmed: 1583625.

33. Hummel SL, DeFranco AC, Skorcz S, et al. Recommendation of low-salt diet and short-term outcomes in heart failure with preserved systolic function. Am J Med. 2009; 122(11): 1029-1036, doi: 10.1016/j.amjmed.2009.04.025, indexed in Pubmed: 19854331

34. Forte JG, Miguel JM, Miguel MJ, et al. Salt and blood pressure: a community trial. J Hum Hypertens. 1989; 3(3): 179-184, indexed in Pubmed: 2671369.

35. Laatikainen T, Pietinen P, Valsta L, et al. Sodium in the Finnish diet: 20-year trends in urinary sodium excretion among the adult population. Eur J Clin Nutr. 2006; 60(8): 965-970, doi: 10.1038/sj.ejcn.1602406, indexed in Pubmed: 16482074.

36. He J, Ogden LG, Vupputuri S, et al. Dietary sodium intake and subsequent risk of cardiovascular disease in overweight adults. JAMA. 1999; 282(21): 2027-2034, doi: 10.1001/ jama.282.21.2027, indexed in Pubmed: 10591385.

37. Kojuri J, Rahimi R. Effect of „no added salt diet” on blood pressure control and 24 hour urinary sodium excretion in mild to moderate hypertension. BMC Cardiovasc Disord. 2007; 7: 34, doi: 10.1186/1471-2261-7-34, indexed in Pubmed: 17986327.

38. Elliott P, Walker LL, Little MP, et al. Change in salt intake affects blood pressure of chimpanzees: implications for human populations. Circulation. 2007; 116(14): 1563-1568, doi: 10.1161/CIRCULATIONAHA.106.675579, indexed in Pubmed: 17785625

39. Jürgens G, Graudal NA, Jürgens $G$, et al. Effects of low sodium diet versus high sodium diet on blood pressure, renin, aldosterone, catecholamines, cholesterols, and triglyceride. Cochrane Database Syst Rev. 2003(1): CD004022, doi: 10.1002/14651858. CD004022, indexed in Pubmed: 12535503.

40. He FJ, MacGregor GA. Effect of modest salt reduction on blood pressure: a meta-analysis of randomized trials. Implications for public health. J Hum Hypertens. 2002; 16(11): 761-770, doi: 10.1038/sj.jhh.1001459, indexed in Pubmed: 12444537.

41. Melander O, von Wowern F, Frandsen E, et al. Moderate salt restriction effectively lowers blood pressure and degree of salt sensitivity is related to baseline concentration of renin and $\mathrm{N}$-terminal atrial natriuretic peptide in plasma. J Hypertens. 2007; 25(3): 619-627, doi: 10.1097/HJH.0b013e328013cd50, indexed in Pubmed: 17278979.

42. Takahashi Y, Sasaki S, Okubo S, et al. Blood pressure change in a free-living population-based dietary modification study in Japan. J Hypertens. 2006; 24(3): 451-458, doi: 10.1097/01. hjh.0000209980.36359.16, indexed in Pubmed: 16467647.

43. Cardiovascular Disease Prevention. Public Health Guidance [PH25]. https://www.nice.org.uk/guidance/PH25.

44. Stolarz-Skrzypek K, Kawecka-Jaszcz K. Ograniczenie spożycia soli kuchennej jako metoda prewencji nadciśnienia tętniczego. Postępy Nauk Medycznych. 2009; 1: 34-38.

45. Meneton P, Jeunemaitre X, de Wardener HE, et al. Links between dietary salt intake, renal salt handling, blood pressure, and cardiovascular diseases. Physiol Rev. 2005; 85(2): 679-715, doi: 10.1152/physrev.00056.2003, indexed in Pubmed: 15788708 .

46. Serafin WE. Dietary Salt Intake and Blood Pressure. JAMA. 1984; 251(11): 1429-1430, doi: 10.1001/jama.1984.03340350023012, indexed in Pubmed: 6700033.

47. Greenland P. Beating high blood pressure with low-sodium DASH. N Engl J Med. 2001; 344(1): 53-55, doi: 10.1056/ NEJM200101043440109, indexed in Pubmed: 11136961.

48. Whelton PK, Appel LJ, Espeland MA, et al. Sodium reduction and weight loss in the treatment of hypertension in older persons: a randomized controlled trial of nonpharmacologic interventions in the elderly (TONE). TONE Collaborative Research Group. JAMA. 1998; 279(11): 839-846, doi: 10.1001/jama.279.11.839, indexed in Pubmed: 9515998.

49. Stamler J, Elliott P, Dyer AR, et al. Commentary: Sodium and blood pressure in the Intersalt study and other studies — in reply to the Salt Institute. BMJ. 1996; 312(7041): 1285-1287, doi: $10.1136 / \mathrm{bmj} .312 .7041 .1285$.

50. McGregor GA, Markandu ND, Sagnella GA, et al. Double-blind study of free sodium intakes and long-term effects of sodium restriction in essential hypertension. Lancet. 1989; 2(8674): 1244-1247, doi: 10.1016/s0140-6736(89)91852-7, indexed in Pubmed: 2573761.

51. Li J, White J, Guo L, et al. Salt inactivates endothelial nitric oxide synthase in endothelial cells. J Nutr. 2009; 139(3): 447-451, doi: 10.3945/jn.108.097451, indexed in Pubmed: 19176751.

52. Gu JW, Anand V, Shek EW, et al. Sodium induces hypertrophy of cultured myocardial myoblasts and vascular smooth muscle cells. Hypertension. 1998; 31(5): 1083-1087, doi: 10.1161/01. hyp.31.5.1083, indexed in Pubmed: 9576118.

53. Cook NR, Cutler JA, Obarzanek E, et al. Long term effects of dietary sodium reduction on cardiovascular disease outcomes: observational follow-up of the trials of hypertension prevention (TOHP). BMJ. 2007; 334(7599): 885-888, doi: 10.1136/ bmj.39147.604896.55, indexed in Pubmed: 17449506.

54. Katori M, Majima M. A missing link between a high salt intake and blood pressure increase. J Pharmacol Sci. 2006; 100(5): 370-390, doi: 10.1254/jphs.crj06003x, indexed in Pubmed: 16651701.

55. Stamler J. The INTERSALT Study: background, methods, findings, and implications. Am J Clin Nutr. 1997; $65(2$ Suppl): 626S-642S, doi: 10.1093/ajcn/65.2.626S, indexed in Pubmed: 9022559.

56. Dahl LK. Possible role of salt intake in the development of essential hypertension. 1960. Int J Epidemiol. 2005; 34(5): 
967-72; discussion 972, doi: 10.1093/ije/dyh317, indexed in Pubmed: 16143660 .

57. Cappuccio FP. Cardiovascular and other effects of salt consumption. Kidney Int Suppl (2011). 2013; 3(4): 312-315, doi: 10.1038/kisup.2013.65, indexed in Pubmed: 25019010.

58. Ferrara LA, de Simone G, Pasanisi F, et al. Left ventricular mass reduction during salt depletion in arterial hypertension. Hypertension. 1984; 6(5): 755-759, doi: 10.1161/01.hyp.6.5.755, indexed in Pubmed: 6238910.

59. Jula AM, Kranko HM. Effect on left ventricular hypertrophy of long-term nonpharmagological treatment with sodium restriction in mild-to-moderate essential hypertension. Circulation. 1994; 89(3): 1023-1031, doi: 10.1161/01.cir.89.3.1023, indexed in Pubmed: 8124787.

60. Kagiyama S, Koga T, Kaseda S, et al. Correlation between increased urinary sodium excretion and decreased left ventricular diastolic function in patients with type 2 diabetes mellitus. Clin Cardiol. 2009; 32(10): 569-574, doi: 10.1002/clc.20664, indexed in Pubmed: 19911350.

61. Yu HC, Burrell LM, Black MJ, et al. Salt induces myocardial and renal fibrosis in normotensive and hypertensive rats. Circulation. 1998; 98(23): 2621-2628, doi: 10.1161/01.cir.98.23.2621, indexed in Pubmed: 9843472.

62. Tuomilehto J, Jousilahti P, Rastenyte D, et al. Urinary sodium excretion and cardiovascular mortality in Finland: a prospective study. Lancet. 2001; 357(9259): 848-851, doi: 10.1016/s01406736(00)04199-4, indexed in Pubmed: 11265954.

63. Verhave JC, Hillege HL, Burgerhof JGM, et al. PREVEND Study Group. Sodium intake affects urinary albumin excretion especially in overweight subjects. J Intern Med. 2004; 256(4): 324-330, doi: 10.1111/j.1365-2796.2004.01390.x, indexed in Pubmed: 15367175 .

64. Swift PA, Markandu ND, Sagnella GA, et al. Modest salt reduction reduces blood pressure and urine protein excretion in black hypertensives: a randomized control trial. Hypertension. 2005; 46(2): 308-312, doi: 10.1161/01.HYP.0000172662.12480.7f, indexed in Pubmed: 15983240.

65. Bernardi S, Toffoli B, Zennaro C, et al. High-salt diet increases glomerular ACE/ACE2 ratio leading to oxidative stress and kidney damage. Nephrol Dial Transplant. 2012; 27(5): 1793-1800, doi: 10.1093/ndt/gfr600, indexed in Pubmed: 22036945.

66. Devine A, Criddle RA, Dick IM, et al. A longitudinal study of the effect of sodium and calcium intakes on regional bone density in postmenopausal women. Am J Clin Nutr. 1995; 62(4): 740-745, doi: 10.1093/ajen/62.4.740, indexed in Pubmed: 7572702 .

67. Burger H, Grobbee DE, Drüeke T. Osteoporosis and salt intake. Nutr Metab Cardiovasc Dis. 2000; 10(1): 46-53, indexed in Pubmed: 10812587.

68. Li H, Han X, Hu Z, et al. Associations of NADPH oxidaserelated genes with blood pressure changes and incident hypertension: The GenSalt Study. J Hum Hypertens. 2018; 32(4): 287-293, doi: 10.1038/s41371-018-0041-6, indexed in Pubmed: 29463833.

69. He FJ, Markandu ND, Sagnella GA, et al. Effect of salt intake on renal excretion of water in humans. Hypertension. 2001; 38(3): 317-320, doi: 10.1161/01.hyp.38.3.317, indexed in Pubmed: 11566897.

70. D'Elia L, Rossi G, Ippolito R, et al. Habitual salt intake and risk of gastric cancer: a meta-analysis of prospective studies. Clin Nutr. 2012; 31(4): 489-498, doi: 10.1016/j.clnu.2012.01.003, indexed in Pubmed: 22296873.

71. González SA, Forcada P, de Cavanagh EMV, et al. Sodium intake is associated with parasympathetic tone and metabolic parameters in mild hypertension. Am J Hypertens. 2012; 25(5): 620-624, doi: 10.1038/ajh.2012.10, indexed in Pubmed: 22357414.
72. Głuszek J. Ograniczenie podaży soli w diecie powinno być powszechnie zalecane. 12 Katowickie Seminarium „Postępy w nefrologii i nadciśnieniu tętniczym”, Katowice 2012.

73. Szyndler A, et al. Summary of the article: Stolarz-Skrzypek K, Kuznetsova T, Thijs L Fatal and nonfatal outcomes, incidence of hypertension, and blood pressure changes in relation to urinary sodium excretion. JAMA, 2011; 305: 1777-1785. Kardiol Pol. 2011; 69: 1314-1315.

74. Kiowski W, Jordan J. Działania niefarmakologiczne. Nadciśnienie Tętnicze. Podręcznik European Society of Hypertension. Via Medica, Gdańsk 2009.

75. Tikellis C, Pickering RJ, Tsorotes D, et al. Activation of the Renin-Angiotensin system mediates the effects of dietary salt intake on atherogenesis in the apolipoprotein $\mathrm{E}$ knockout mouse. Hypertension. 2012; 60(1): 98-105, doi: 10.1161/HYPERTENSIONAHA.112.191767, indexed in Pubmed: 22647892.

76. He F, MacGregor G. Effect of longer-term modest salt reduction on blood pressure. Cochrane Database Syst Rev. 2004; 4(CD004937), doi: 10.1002/14651858.cd004937, indexed in Pubmed: 23633321.

77. Alderman MH, Cohen HW, Alderman MH, et al. Dietary sodium intake and cardiovascular mortality: controversy resolved? Am J Hypertens. 2012; 25(7): 727-734, doi: 10.1038/ajh.2012.52, indexed in Pubmed: 22627176.

78. Guyton AC. Kidneys and fluids in pressure regulation. Small volume but large pressure changes. Hypertension. 1992; 19(1 Suppl): I2-I8, doi: 10.1161/01.hyp.19.1_suppl.i2, indexed in Pubmed: 1730451.

79. Kanbay M, Chen Y, Solak Y, et al. Mechanisms and consequences of salt sensitivity and dietary salt intake. Curr Opin Nephrol Hypertens. 2011; 20(1): 37-43, doi: 10.1097/ MNH.0b013e32834122f1, indexed in Pubmed: 21088577.

80. Iwamoto $\mathrm{T}$. $\mathrm{Na}+/ \mathrm{Ca} 2+$ exchange as a drug target — insights from molecular pharmacology and genetic engineering. Ann NY Acad Sci. 2007; 1099: 516-528, doi: 10.1196/annals.1387.039, indexed in Pubmed: 17446496.

81. Lifton RP, Gharavi AG, Geller DS. Molecular mechanisms of human hypertension. Cell. 2001; 104(4): 545-556, doi: 10.1016/ s0092-8674(01)00241-0, indexed in Pubmed: 11239411.

82. Surma S, Romańczyk M, Bańkowski E. [The role of limiting sodium intake in the diet — from theory to practice]. Folia Cardiol. 2020; 15(3): 59-132, doi: 10.5603/FC.2020.0030.

83. World Health Organisation (WHO). Guideline: sodium intake in adults and children. WHO, Geneva 2012.

84. Williams B, Mancia G, Spiering W, et al. Authors/Task Force Members:, ESC Scientific Document Group . 2018 ESC/ESH Guidelines for the management of arterial hypertension. Eur Heart J. 2018; 39(33): 3021-3104, doi: 10.1093/eurheartj/ ehy339, indexed in Pubmed: 30165516.

85. Tykarski A, Filipiak KJ, Januszewicz A, et al. Zasady postępowania w nadciśnieniu tętniczym — 2019 rok Wytyczne Polskiego Towarzystwa Nadciśnienia Tętniczego. Nadciśnienie Tętnicze w Praktyce. 2019; 5: 1-86.

86. Szybiński Z, Jarosz M, Hubalewska-Dydejczyk A, et al. [Iodinedeficiency prophylaxis and the restriction of salt consumption - a 21st century challenge]. Endokrynol Pol. 2010; 61 Suppl 1(1): 1-6, indexed in Pubmed: 22127630.

87. Szybiński Z, Brzośka F, Śliwiński B. Iodine concentration in ish milk - variations due to season and region. Pol J Endocrinol. 2009; 60: 449-454.

88. Ziemlański Ś, Zawistowska Z. Kuchnia dietetyczna z solą czy bez soli. Warta, Warszawa 1991.

89. Chang HY, Hu YW, Yue CSJ, et al. Effect of potassium-enriched salt on cardiovascular mortality and medical expenses of elderly men. Am J Clin Nutr. 2006; 83(6): 1289-1296, doi: 10.1093/ ajcn/83.6.1289, indexed in Pubmed: 16762939. 